\title{
PUSAT KOMUNITAS SEPEDA DI KOTA PONTIANAK
}

\author{
Elicia Javiera ${ }^{1}$, Uray Fery Andi², Yudi Purnomo ${ }^{3}$ \\ ${ }^{1}$ Mahasiswa, Program Studi Arsitektur, Fakultas Teknik, Universitas Tanjungpura. \\ ellicia.javiera@gmail.com \\ ${ }^{2}$ Jurusan Arsitektur, Fakultas Teknik, Universitas Tanjungpura \\ ${ }^{3}$ Jurusan Arsitektur, Fakultas Teknik, Universitas Tanjungpura
}

Naskah diajukan pada: 7 Juli 2021

Naskah revisi akhir diterima pada: 8 Juli 2021

\begin{abstract}
Abstrak
Sepeda merupakan transportasi darat yang berkelanjutan. Latar belakang perancangan ini, yakni tren bersepeda di Kota Pontianak sudah ada sejak tahun 2000. Pada tahun 2005 terbentuk komunitas Bike to Work dan hingga saat ini terbentuk lebih dari 20 komunitas sepeda di Kota Pontianak. Anggota komunitas sepeda membutuhkan wadah untuk tempat berkumpul dan berbagi minat terhadap sepeda, serta masyarakat membutuhkan tempat yang aman untuk bermain dan berlatih sepeda. Perancangan ini sejalan dengan komitmen Pemerintah Kota Pontianak untuk mewujudkan Kota Pontianak sebagai kota yang ramah sepeda. Tujuan utama dari perancangan ini, yakni menyediakan titik kumpul (meeting point) yang interaktif, fleksibel, dan mengkombinasikan bentuk roda sepeda sebagai bagian dari perancangan. Metode desain yang digunakan adalah metode desain Robert Whitaker, yang terdiri atas tahap pengenalan, tahap definisi, tahap persiapan, tahap analisis, tahap sintesis, tahap evaluasi, dan tahap re-evaluasi. Konsep utama dalam perancangan ini adalah menciptakan delapan klaster komunitas sepeda yang terintegrasi dengan area komersil, rekreasi, dan edukasi untuk memenuhi kebutuhan dan gaya hidup pesepeda di Kota Pontianak. Perancangan ini menghasilkan area plaza dengan susunan delapan klaster sepeda yang memusat dan terintegrasi dengan area komersil, waterfront, food court, dan area freestyle dengan organisasi klaster.
\end{abstract}

Kata-kata Kunci: Komunitas Sepeda, Tempat Berkumpul, Kota Pontianak

\begin{abstract}
Bicycle is the sustainable land transport. The background of this design is the cycling trend in Pontianak City has existed since 2000. In 2005 the Bike to Work community was formed and until now more than 20 bicycle communities have been formed in Pontianak City. Members of the cycling community need a place to gather and share their interest in cycling, and people need a safe place to play and practice cycling. This design is in line with the commitment of the Pontianak City Government to realize Pontianak City as a bicycle-friendly city. The main purpose is to provide an interactive, flexible, and combine meeting point with the shape of bicycle wheels as part of the design. The design used the Whitaker design method, which consists of the introduction stage, definition stage, preparation stage, analysis stage, synthesis stage, evaluation stage, and re-evaluation stage. The main concept is to create eight bicycle community clusters that are integrated with commercial, recreational, and educational areas to meet the needs and lifestyles of cyclists. This design produces a plaza area with an arrangement of eight bicycle clusters that are centralized and integrated with a commercial area, waterfront, food court, and freestyle area with cluster organization.
\end{abstract}

Keywords: Bicycle Community, Gathering Place, Pontianak City

\section{Pendahuluan}

Tren sepeda di Kota Pontianak sudah berlangsung sejak tahun 2000. Pada tahun 2005 terbentuk komunitas Bike to Work dan hingga saat ini sudah terbentuk lebih dari 20 komunitas sepeda di Kota Pontianak. Menurut hasil wawancara dengan Yeda, salah satu pencetus Selasar (Selasa Sepeda Ria), tren sepeda di Kota Pontianak meningkat tiap 10 tahun, yakni pada tahun 2010 
dan tahun 2020 Tren sepeda pada 2010 lebih rendah dibandingkan tahun 2020 karena tren hanya terjadi pada jenis sepeda fixie. Tren sepeda pada tahun 2020 terjadi pada semua jenis sepeda karena dampak pandemi saat masa new normal. Pemerintah Kota (Pemkot) Pontianak juga berkomitmen untuk mewujudkan Kota Pontianak sebagai kota yang ramah sepeda. Saat ini Pemkot sedang menyediakan jalur-jalur pesepeda sebagai jalur yang aman bagi pesepeda di Kota Pontianak.

Namun, fasilitas jalur pesepeda belum cukup memenuhi kebutuhan pesepeda di Kota Pontianak. Anggota komunitas sepeda memerlukan wadah untuk tempat berkumpul, berbagi minat terhadap sepeda, sarana edukasi, dan sarana rekreasi. Taman-taman di Kota Pontianak juga belum mengedukasi masyarakat mengenai sepeda, seperti edukasi mengenai parkir sepeda, jalur khusus sepeda, dan fasilitas yang dibutuhkan pesepeda. Kebutuhan pesepeda di taman-taman Kota Pontianak juga belum terpenuhi, serta belum terdapat taman khusus pesepeda yang dapat memenuhi kebutuhan pesepeda harian, seperti kebutuhan membersihkan diri dengan mandi. Masyarakat di Kota Pontianak juga membutuhkan tempat yang aman untuk bermain dan berlatih sepeda.

Pusat Komunitas Sepeda di Kota Pontianak bertujuan untuk menyediakan wadah bagi anggota komunitas sepeda dan masyarakat umum untuk berkumpul, berbagi minat terhadap sepeda, sarana edukasi, dan sarana rekreasi. Hasil rancangan Pusat Komunitas Sepeda di Kota Pontianak diharapkan dapat mempertahankan dan meningkatkan tren bersepeda sebagai alat transportasi ramah lingkungan dan menciptakan ikon atau wajah baru bagi Kota Pontianak sebagai kota yang ramah sepeda.

\section{Kajian Pustaka}

Menurut Becker et al. (2018), sepeda merupakan sarana transportasi yang berkelanjutan dan terbukti memberikan kontribusi yang signifikan dalam menjadikan kota sebagai tempat tinggal yang menarik. Bersepeda berkontribusi menciptakan kota yang layak huni, menciptakan transportasi perkotaan yang efisien, mengurangi kemacetan dan kebisingan lalu lintas, menyehatkan tubuh, menciptakan udara yang bersih, mengatasi perubahan iklim, menghemat bahan bakar fosil, dan menciptakan pariwisata yang berkelanjutan. Secara umum sepeda terdiri atas frame, roda, setang, pedal, sadel, roda gigi, dan rem (Stevenson, 2003).

Menurut Stevenson (2003), jenis sepeda dibagi menjadi tiga kelompok, yaitu sepeda untuk orang dewasa, sepeda untuk anak-anak, dan sepeda BMX. Pada kelompok sepeda dewasa, terdapat dua kelompok berdasarkan penggunaanya, yakni sepeda untuk pria dan sepeda untuk wanita. Menurut Häussermann (2020), sepeda listrik juga mengalami perkembangan yang signifikan. Tidak hanya untuk orang yang lebih tua atau kurang atletis, sepeda listrik turut membantu pesepeda menjadi lebih aktif lagi, terutama untuk mereka yang sebelumnya kekurangan motivasi atau pengalaman bersepeda, dan untuk mereka yang khawatir kehabisan energi sebelum mencapai tujuan mereka.

Pusat Komunitas Sepeda di Kota Pontianak berkaitan erat dengan arsitektur lansekap. Menurut Hakim (2012), arsitektur lansekap adalah ilmu dan seni perencanaan, perancangan, dan pengaturan terhadap lahan, penyusunan elemen-elemen alam dan buatan melalui aplikasi ilmu pengetahuan dan budaya, dengan memperhatikan keseimbangan kebutuhan pelayanan dan pemeliharaan sumber daya, hingga tercipta lingkungan yang fungsional dan estetis.

Menurut Hakim (2012), unsur desain lansekap terdiri atas unsur garis, bentuk, warna, dan tekstur. Prinsip desain lansekap yang digunakan untuk mencapai suatu kesatuan dan keteraturan, yakni keseimbangan, irama dan pengulangan, penekanan, kesederhanaan, kontras, proporsi, space, dan kesatuan. Arsitektur Lansekap pada dasarnya terdapat dua bagian besar material lansekap, yakni material lunak (soft materials) dan material keras (hard materials).

Menurut Ching (2008), organisasi ruang spasial terdiri atas organisasi terpusat, linier, radial, klaster, dan grid. Organisasi terpusat merupakan organisasi yang stabil, terkonsentrasi, dan bersifat mempersatukan. Organisasi linier bersifat fleksibel dan sigap merespon beragam kondisi tapak dengan cara menyambung dan mengorganisir bentuk lain di sepanjang jalurnya. Organisasi radial mengkombinasikan elemen organisasi linier maupun terpusat demi merespon kebutuhan fungsi dan 
lingkungan dan menghasilkan susunan pola dinamis. Organisasi klaster terdiri dari ruang-ruang berulang dan seluler yang memiliki fungsi dan fleksibel, serta siap bertumbuh dan berubah tanpa mempengaruhi karakternya. Prinsip bentuk dan ruang diperlukan untuk menciptakan tatanan dalam komposisi arsitektural yang harmonis.

\section{Metode}

Metode desain yang digunakan adalah metode desain yang dikemukakan oleh Robert Whitaker yang terdiri atas tahap pengenalan, tahap definisi, tahap persiapan, tahap analisis, tahap sintesis, tahap evaluasi, dan tahap re-evaluasi (Snyder \& Catanese, 1989). Tahap pengenalan dimulai berdasarkan pola pikir terhadap isu-isu yang menjadi latar belakang pusat komunitas sepeda. Tahap definisi berdasarkan latar belakang masalah dengan membaca berita yang beredar mengenai komunitas sepeda, wawancara, dan studi literatur. Tahap persiapan dengan melakukan pengumpulan data primer yang diperoleh dari observasi lokasi eksisting dan wawancara dengan anggota komunitas sepeda di Kota Pontianak, serta mengumpulkan data sekunder dari studi literatur dan studi kasus (preseden).

Tahap analisis dilakukan untuk menganalisis data-data yang telah dikumpulkan, berupa analisis fungsi, analisis pelaku, analisis ruang, analisis lokasi, analisis tapak, analisis bentuk, analisis struktur, analisis utilitas, dan analisis fisika bangunan. Tahap sintesis menghasilkan kerangka besar sebagai gambaran pemikiran dengan hasil akhir berupa skematik ruang luar dan skematik ruang dalam, serta gubahan bentuk yang menjelaskan penerapan analisis bentuk, struktur, utilitas, dan fisika bangunan. Tahap evaluasi adalah tahap menyusun konsep perancangan dan perencanaan. Tahap re-evaluasi merupakan tahapan pemeriksa kembali hasil akhir dokumentasi yaitu gambar pra rancangan, gambar rencana arsitektural, gambar rencana struktural, gambar rencana utilitas.

\section{Hasil dan Pembahasan}

Lokasi perancangan secara makro berada di Kota Pontianak, Kalimantan Barat. Analisis lokasi perancangan berdasarkan kriteria lokasi dengan modifikasi dari acuan (Chiara dan Koppelman, 1978), yaitu rute yang sering dilalui pesepeda dan komunitas sepeda supaya sesuai dengan fungsi perancangan dan fasilitas sekitar tapak memenuhi kebutuhan perancangan. Fasilitas yang terpenuhi, seperti kedekatan terhadap pasar, ketersediaan listrik, ketersediaan air, perlindungan terhadap bahaya kebakaran, perlindungan polisi, fasilitas sekolah, dan fasilitas peribadatan.

Lokasi perancangan Pusat Komunitas Sepeda di Kota Pontianak berada di Jalan Ahmad Yani, Kecamatan Pontianak Selatan. Lokasi ini bersebelahan dengan GOR Pangsuma sebagai pelengkap sarana olahraga. Di samping tapak juga terdapat parit, sebagai elemen pelengkap lansekap. Berdasarkan Perda No 2 Tahun 2013 tentang RTRW Kota Pontianak tahun 2013- 2033 dan Dinas Cipta Karya Tata Ruang mengenai data peraturan lingkungan dengan ketentuan tapak antara lain, peruntukan lahan berupa Ruang Terbuka Hijau (RTH) sebagai pelengkap sarana olahraga. Berdasarkan data ukuran dan tata wilayah, luas tapak adalah $8.285 \mathrm{~m}^{2}$ dengan eksisting di depan tapak terdapat trotoar dengan jalur sepeda terproteksi dengan total lebar trotoar 7,5 m. KDB 20\% $\left(1.657 \mathrm{~m}^{2}\right)$, KDH $80 \%\left(6.628 \mathrm{~m}^{2}\right)$, dan KLB 0,4 $\left(3.314 \mathrm{~m}^{2}\right)$. Luas tapak dikurangi GSB, GSS, dan sempadan sungai menjadi $4.344 \mathrm{~m}^{2}$.

Sirkulasi menuju tapak terdiri atas tiga jalur. Jalur utama dari Jalan Ahmad Yani di depan tapak, sedangkan jalur kedua dan jalur ketiga dari Jalan Letkol Soegiono di kiri dan belakang tapak. Aktivitas manusia dan lingkungan di sekitar tapak, yaitu sering dilalui pesepeda pada Jalan Ahmad Yani dan Jalan Letkol Soegiono. Pada area GOR Pangsuma, biasa digunakan para atlit untuk berlatih. Pada area belakang tapak, terdapat GKII Ekklesia, sehingga biasa dilalui juga oleh masyarakat yang ibadah. 


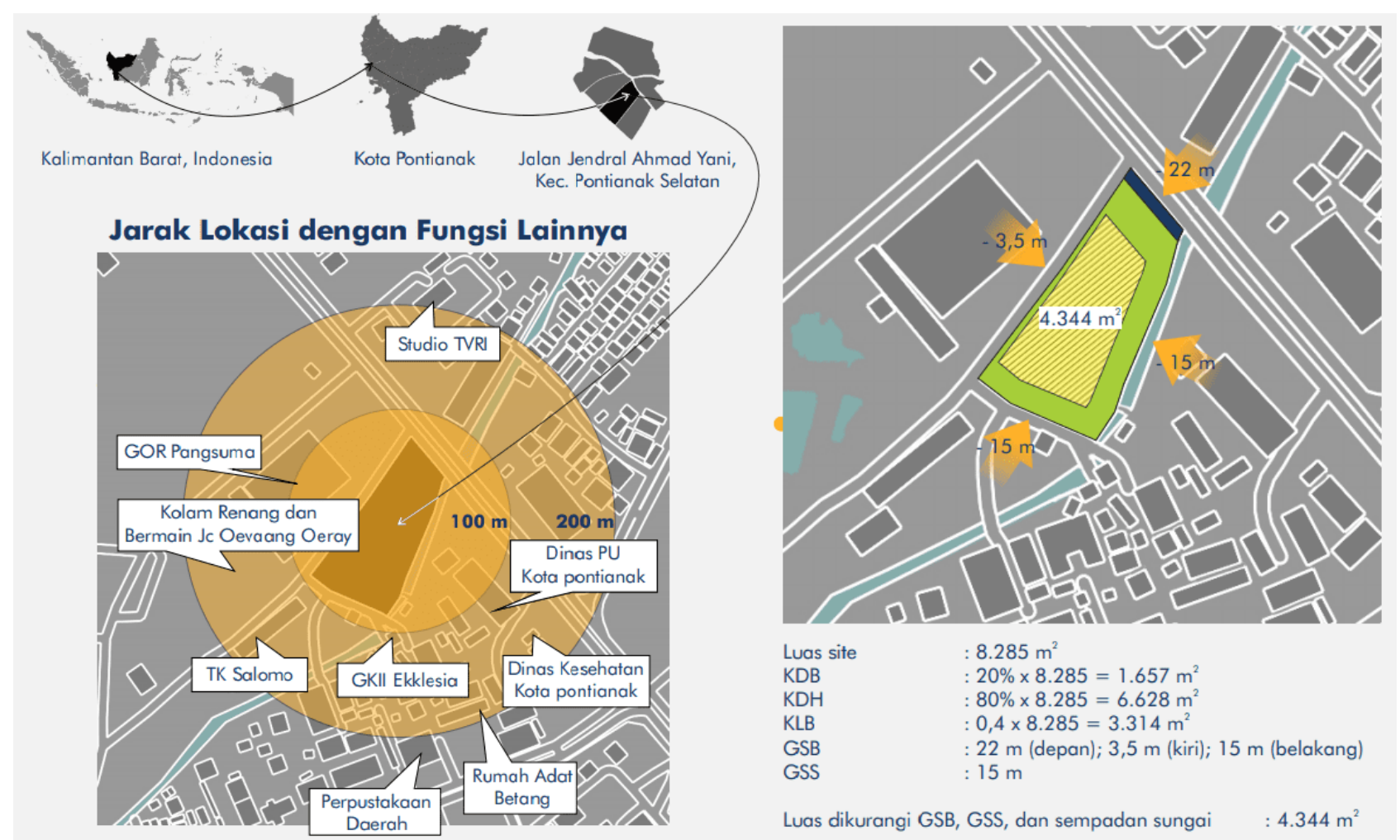

Gambar 1. Lokasi dan Ukuran Tapak

Sumber: Penulis, 2021

\section{Landasan Konseptual}

Landasan konseptual merupakan proses analisis terhadap data-data yang didapatkan untuk mencapai tujuan perancangan. Proses awal analisis adalah indentifikasi permasalahan untuk mendapatkan solusi perancangan. Fungsi rancangan Pusat Komunitas Sepeda di Kota Pontianak terdiri atas tiga kelompok fungsi. Fungsi utama sebagai tempat berkumpul (meeting point) bagi pesepeda di Kota Pontianak berupa titik kumpul awal dan akhir untuk berdiskusi rute dan tempat dokumentasi kegiatan bersepeda. Fungsi penunjang terdiri atas fungsi komersil untuk memenuhi kebutuhan dan gaya hidup pesepeda, fungsi rekreasi berupa ruang terbuka bagi pesepeda untuk bersantai dan mendinginkan diri setelah bersepeda, dan fungsi edukasi berupa tempat aman untuk pesepeda latihan keseimbangan di tempat yang aman dan didampingi bimbingan instruktur. Fungsi pendukung terdiri atas fungsi pengelola untuk mengelola kebutuhan dan fasilitas dalam perancangan dan fungsi supplier untuk mengelola pasokan barang demi terpenuhinya kebutuhan fungsi komersil.

Pelaku Pusat Komunitas Sepeda di Kota Pontianak dikelompokkan berdasarkan tiga kelompok fungsi. Pelaku pada fungsi utama sebagai tempat berkumpul terdiri atas pesepeda komunitas sepeda dan pesepeda umum. Pelaku pada fungsi penunjang untuk fungsi komersil terdiri atas pembeli, pelayan toko, dan kasir; fungsi rekreasi terdiri atas pengunjung umum dan pengunjung disabilitas; dan fungsi edukasi terdiri atas instruktur dan murid. Pelaku pada fungsi pendukung untuk fungsi pengelola terdiri atas direktur, sekretaris, tamu, manajer, staf kerja, dan pemeliharaan dan perawatan gedung, sedangkan pada fungsi supplier terdiri atas kelapa gudang, staf gudang, dan buruh gudang.

Kebutuhan ruang Pusat Komunitas Sepeda di Kota Pontianak berjumlah 35 ruang dan dikelompokkan berdasarkan enam fungsi. Fungsi berkumpul terdiri atas plaza dan klaster komunitas sepeda. Klaster komunitas sepeda terdiri atas sepeda lipat, sepeda balap, sepeda komuter, sepeda fixie, sepeda onthel, sepeda listrik, MTB, dan BMX dan trial. Fungsi komersil terdiri atas food court, toko sepeda, bengkel dan tempat cuci sepeda, toko tempat ganti pakaian dan membersihkan diri, toko tempat sewa dan penyimpanan sepeda, toilet umum, dan toilet disabilitas. Fungsi rekreasi terdiri atas taman, waterfront, dan area freestyle. Fungsi edukasi berupa tempat pelatihan sepeda. Fungsi 
pengelola terdiri atas lobby pengelola, ruang tamu, ruang rapat, ruang direktur, ruang sekretaris, ruang manajer, ruang kerja staf, pantry, dan toilet pengelola. Fungsi supplier terdiri atas pos keamanan, ruang panel, ruang janitor, tempat sampah, area bongkar muat, ruang kepala gudang, dan ruang staf gudang. Kesimpulan total luas minimal untuk rancangan Pusat Komunitas Sepeda di Kota Pontianak adalah $3.162 \mathrm{~m}^{2}$.

Analisis tapak Pusat Komunita Sepeda di Kota Pontianak terdiri atas analisis peletakan, orientasi, sirkulasi, vegetasi, dan zonasi. Peletakan area ruang terbuka atau plaza diletakan di area depan dengan pertimbangan merespon tiga view positif, yakni Jalan Ahmad Yani, GOR Pangsuma, dan parit. Selain itu peletakan area ruang terbuka atau plaza berada di depan merespon fungsi utama perancangan, yakni fungsi berkumpul (meeting point). Peletakan area komersil terintegrasi dengan area freestyle berdampingan dengan area pengelola. Area waterfront diletakkan di sepanjang parit. Area parkir disesuaikan dengan kebutuhan, sehingga dapat diletakkan di depan maupun di belakang tapak.

Orientasi fungsi utama perancangan berupa ruang terbuka atau plaza dibuat memusat untuk merespon jalur sirkulasi orientasi matahari, dan view keluar site seperti GOR Pangsuma, parit, dan lainnya. Orientasi area komersil dan freestyle merespon sirkulasi pada Jalan Letkol Soegiono dan view menuju GOR Pangsuma. Orientasi area belakang tapak tetap merespon sirkulasi pada Jalan Letkol Soegiono. Orientasi waterfront merespon dua arah merespon sisi dalam tapak, seperti ruang terbuka atau plaza dan merespon sisi luar tapak, yakni view parit.

Sirkulasi area plaza dibuat melingkar merespon ruang terbuka di sekitarnya dan view sekitar, serta dapat dibentuk sirkulasi memusat ke area plaza terletak di tengah ruang terbuka untuk mengarahkan pengunjung ke tempat berkumpul yang berada di area plaza. Sirkulasi area pengelola dapat dibuat linier merespon Jalan Letkol Soegiono. Sirkulasi area waterfront dibuat linier merespon jalur parit.

Vegetasi pada area depan menggunakan kombinasi tanaman hias yang dapat meredam kebisingan dari kendaraan yang lewat. Area masuk dapat diberikan tanaman pengarah berupa tanaman heliconia. Area di tepi Jalan Letkol Soegiono diberi tanaman pohon tanjung untuk meredam bising. Area ruang terbuka dapat dibingkai dengan menggunakan tanaman pangkas kuning. Area dekat tepi jalan dapat dikombinasikan antara pohon biola cantik atau kiaya payung dengan tanaman hias, seperti tanaman puring, puring tisu, soka, walisongo, dan pucuk merah.

Zonasi pada zona publik untuk berkumpul sebagai pusat perancangan diletakkan di area depan. Zona publik untuk taman terintegrasi dengan zona publik untuk berkumpul. Zona publik untuk komersil merespon view dan jalur utilitas yang ada. Zona privat untuk pengelola merespon jalur utilitas. Zona servis bangunan berperan sebagai penunjang antara zona pengelola dan zona komersil. Zona servis untuk parkir merespon zona publik untuk berkumpul (depan) dan zona pengelola (belakang).

Gubahan bentuk Pusat Komunitas Sepeda di Kota Pontianak terdiri atas proses desain lansekap dan proses gubahan massa bangunan. Proses desain lansekap menerapkan zoning antara zona publik dan zona privat dengan tata letak fungsi utama untuk berkumpul menggunakan organisasi terpusat, sedangkan fungsi lainnya menggunakan organisasi klaster. Terdapat beberapa hal dalam desain lansekap, yakni penataan lansekap, penataan infrastruktur, tempat parkir, dan penataan area pengelola.

Proses gubahan massa bangunan Pusat Komunitas Sepeda di Kota Pontianak menerapkan analisis internal dan eksternal dengan menggunakan analogi roda sepeda sebagai ciri khas perancangan. Massa bangunan menerapkan keseragaman dengan menggunakan warna netral dan secondary skin berupa corak insang khas Melayu Pontianak. Jalur sirkulasi melingkar yang mengenai area parit ditinggikan dan ditarik menggunakan sistem kabel supaya aliran parit tidak terganggu dan menciptakan kesan jalur sirkulasi yang melayang. 


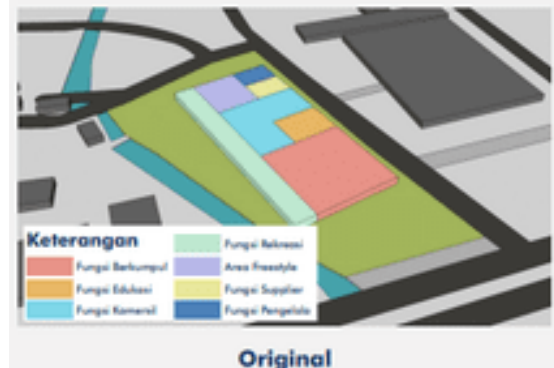

Original

Peletakan fungsi menyesuaikan peraturan, tujuan perancangan, dan hasil analisis yang telah dilakukan

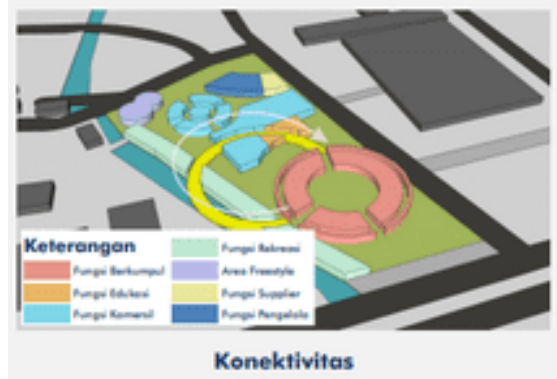

Penambahan jalur sirkulasi melingkar untuk meningkotkon konektivitas ontar fungsi dolom perancangan dan menciptakan pengalaman beru bagi pesepeda untuk bersepeda di jalur melingkar di atos parit. Jalur ini ditinggikan dan ditarik sistem kabel supaya tidak mengganggu aliran parit

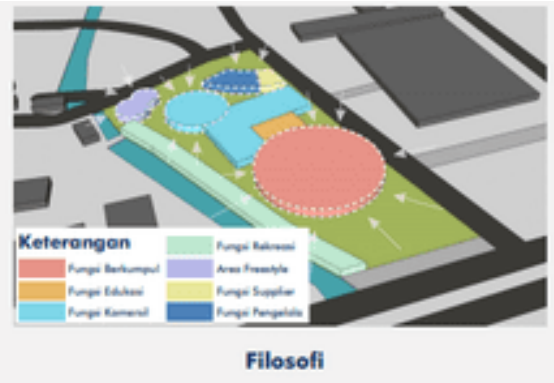

Bentuk massa tiop fungsi mengambil analogi roda sepeda sebogai ciri khas pusat komunitas sepeda. Analogi ini diaplikasikan pada fungsi berkumpul, area freestyle, fungsi komersil, fungsi pengelola, dan fungsi supplier

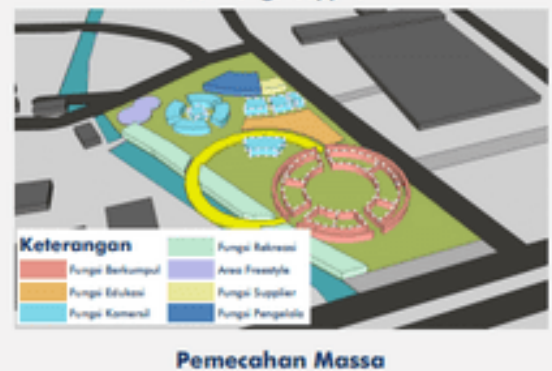

Pemecohen massa poda fungsi berkumpul untuk menciptokan klaster komunitos sepedo dan pemecahon messa komersil

menyesuaikan kebutuhan dan gaya hidup pesepeda di Kota Pontianak

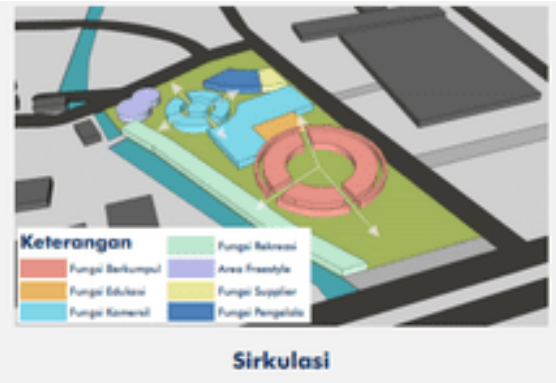

Pengurangan bentuk untuk menyediakan jalur sirkulasi berbentuk radial poda fungsi berkumpul berkumpul dan sirkulasi empat arah pode fungsi komersil

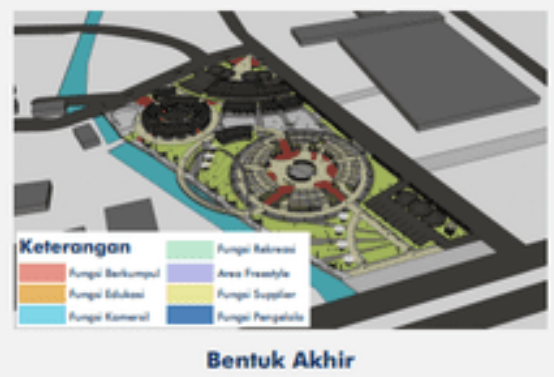

Penambahan secondary skin berupa corak insang poda masso bangunan dan kabel penarik struktur jembatan membentuk ilusi tanjak dari mata manusia dan roda sepeda dari perspektif mata burung

Gambar 2. Proses Gubahan Massa Bangunan Pusat Komunitas Sepeda di Kota Pontianak

Sumber: Penulis, 2021

Konsep bentuk Pusat Komunitas Sepeda di Kota Pontianak menerapkan bentuk dasar dari analogi roda sepeda. Fungsi berkumpul menciptakan klaster sepeda yang disusun memusat dengan view utama ke Jalan Ahmad Yani. Fungsi rekreasi membentuk organisasi linier mengikuti jalur parit. Kedua fungsi ini disatukan oleh sirkulasi melingkar yang menciptakan kesatuan pada perancangan ini. Fungsi pengelola diberi pembatas yang bersifat tidak permanen, yakni menggunakan tanaman pembatas. 


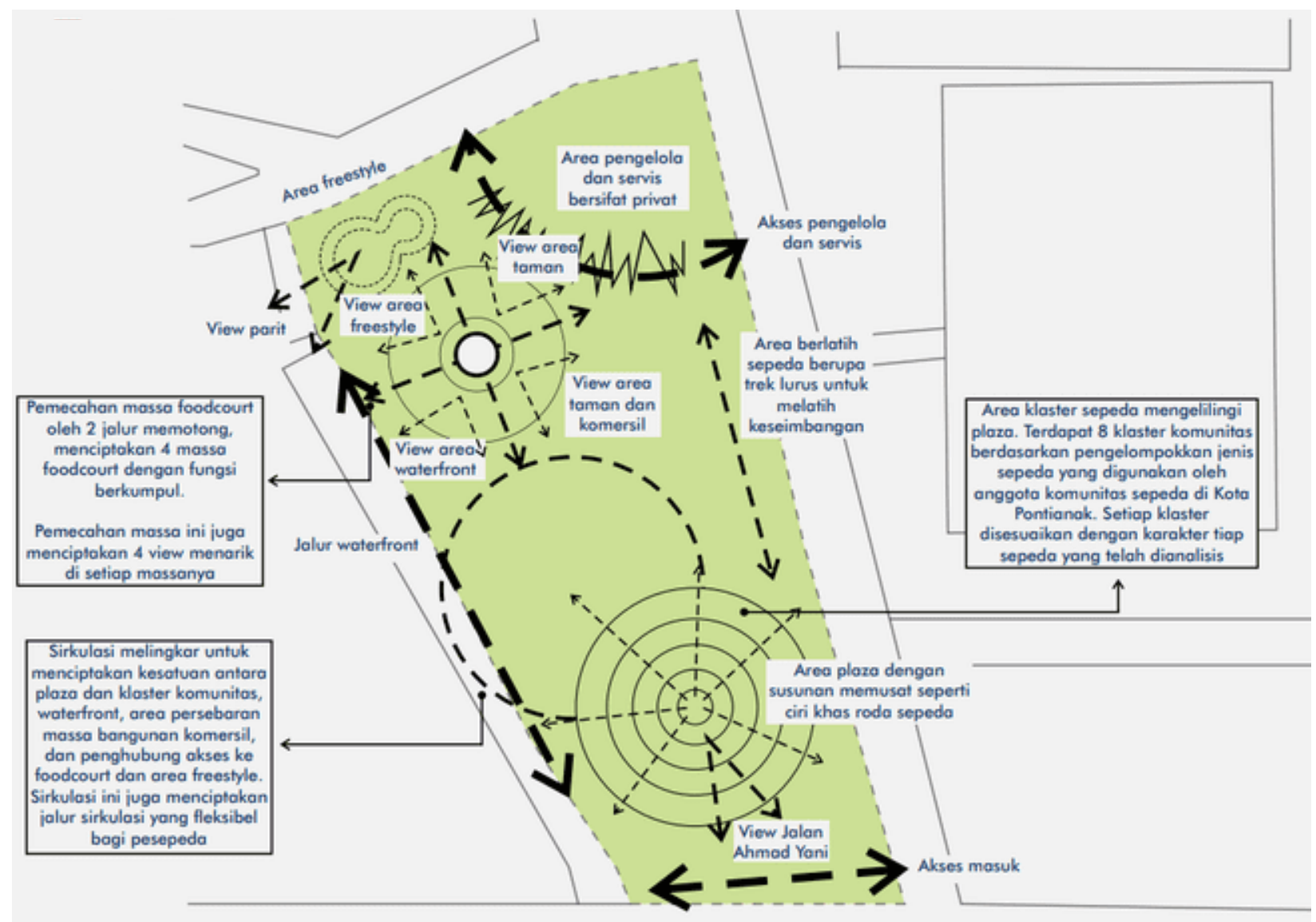

Gambar 3. Konsep Bentuk Pusat Komunitas Sepeda di Kota Pontianak Sumber: Penulis, 2021

Konsep struktur Pusat Komunitas Sepeda di Kota Pontianak menggunakan sistem struktur bangunan tidak bertingkat. Jenis pondasi yang dipilih menggunakan pondasi batu kali dengan sistem menerus yang diperkuat cerucuk kayu. Perancangan sistem struktur berdasarkan analisis besaran ruang menghasilkan bentang bangunan modul 5, 4, dan 3 meter menggunakan rangka beton. Struktur atap menggunakan sistem rangka truss, yakni menggunakan baja WF untuk kuda-kuda atap dan baja profil $\mathrm{C}$ untuk gording atap. Jenis penutup atap dan plafon yang dipilih adalah atap bitumen dan plafon GRC yang bersifat fleksibel, sehingga dapat dibentuk melengkung sesuai dengan kebutuhan perancangan. Konstruksi dinding menggunakan pengisi berupa bata ringan. Konstruksi lantai menggunakan lantai cor beton yang ditutup dengan menggunakan keramik homogen.

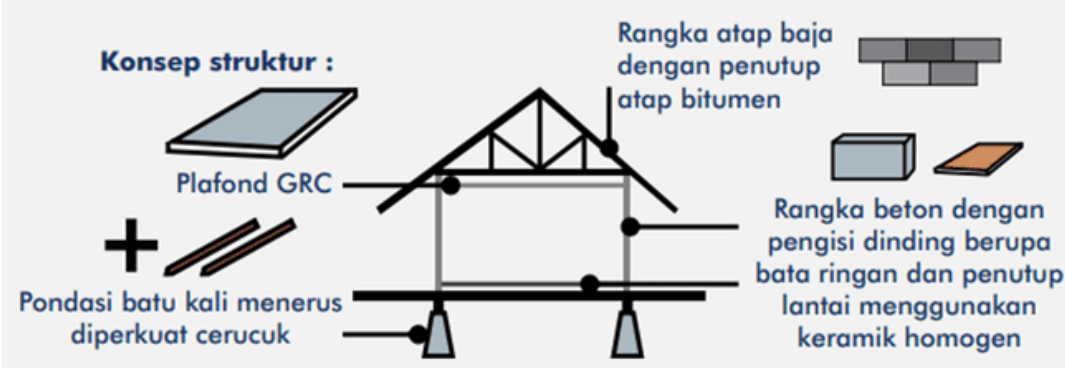

Gambar 4. Konsep Struktur Pusat Komunitas Sepeda di Kota Pontianak Sumber: Penulis, 2021 
Konsep utilitas Pusat Komunitas Sepeda di Kota Pontianak terdiri atas sistem jaringan air, sistem jaringan, sistem tata udara, sistem keamanan bangunan, dan sistem persampahan. Sistem jaringan air bersih menggunakan sistem air up feed system. Air bersih ditampung di tangki bawah (ground water tank), kemudian air dipompa dan disambungkan ke pipa utama untuk disalurkan ke bangunan. Konsep ini dipilih karena cocok dengan perancangan bertingkat rendah dengan harga yang relatif rendah. Sistem jaringan air kotor menggunakan biotank karena lebih ramah lingkungan, awet, tidak mencemari air tanah, tidak berbau, dan daya tampung yang pas.

Sistem jaringan terdiri atas sistem jaringan listrik, sistem jaringan informasi, dan sistem jaringan CCTV. Sistem jaringan listrik berasal dari PLN dan menggunakan jenis lampu LED. Sistem jaringan informasi menggunakan jaringan internet pada fasilitas pengelola dan jaringan tata suara menggunakan sound system sederhana pada fasilitas komersil. Jenis speaker yang digunakan berupa ceiling speaker yang terkoneksi dengan mic paging dan CD Player dengan menggunakan amplifier. Sistem jaringan CCTV menggunakan CCTV indoor dan CCTV outdoor pada fungsi rekreasi, fungsi komersil, dan fungsi pengelola. Konsep CCTV indoor mengutamakan pemantauan area dalam bangunan sepanjang hari, bahkan saat ruangan gelap untuk mengamati barang dagangan supaya terjaga keamanannya. Konsep CCTV outdoor mengutamakan CCTV yang tahan banting dan tidak mudah rusak, yakni tahan sabotase atau vandalproof.

Sistem tata udara mengutamakan keseimbangan sirkulasi udara secara alami dan buatan bergantung kebutuhan pengguna. Konsep penghawaan alami di Kota Pontianak perlu dibantu dengan menggunakan kipas uap dengan kelebihan mudah dirawat, dapat dipindahkan ke luar atau dalam bangunan bergantung kebutuhan, dan sangat efektif untuk penghawaan ruangan yang cukup luas. Konsep penghawaan buatan menggunakan sistem AC standing floor karena lebih hemat listrik dan dapat dipindahkan ke mana saja bergantung kebutuhan, perawatan terjangkau, serta udara yang dihasilkan cenderung normal dan natural.

Sistem keamanan bangunan untuk kebakaram menggunakan sistem sederhana karena bangunan tidak bertingkat. Konsep kebakaran menggunakan APAR tiap 20 meter dan peletakan hidran halaman dengan radius 30 meter. Sistem keamanan bangunan berupa penangkal petir sistem penangkal petir elektrostatis dengan radius 150 meter. Konsep ini dipilih karena sistem ini dirancang khusus untuk daerah tropis seperti Kota Pontianak dengan hari guruh rata-rata $21 \mathrm{kali} / \mathrm{tahun}$.

Sistem persampahan menggunakan tempat sampah yang mengelompokkan sampah ke tiga bagian, yaitu sampah organik, pecah belah, dan plastik. Sampah dari tempat sampah kemudian dikumpulkan dan dibuang ke kontainer sampah. Kontainer sampah yang dipilih menggunakan material fiberglass FRP dilengkapi penutup supaya bau sampah tidak menyebar.

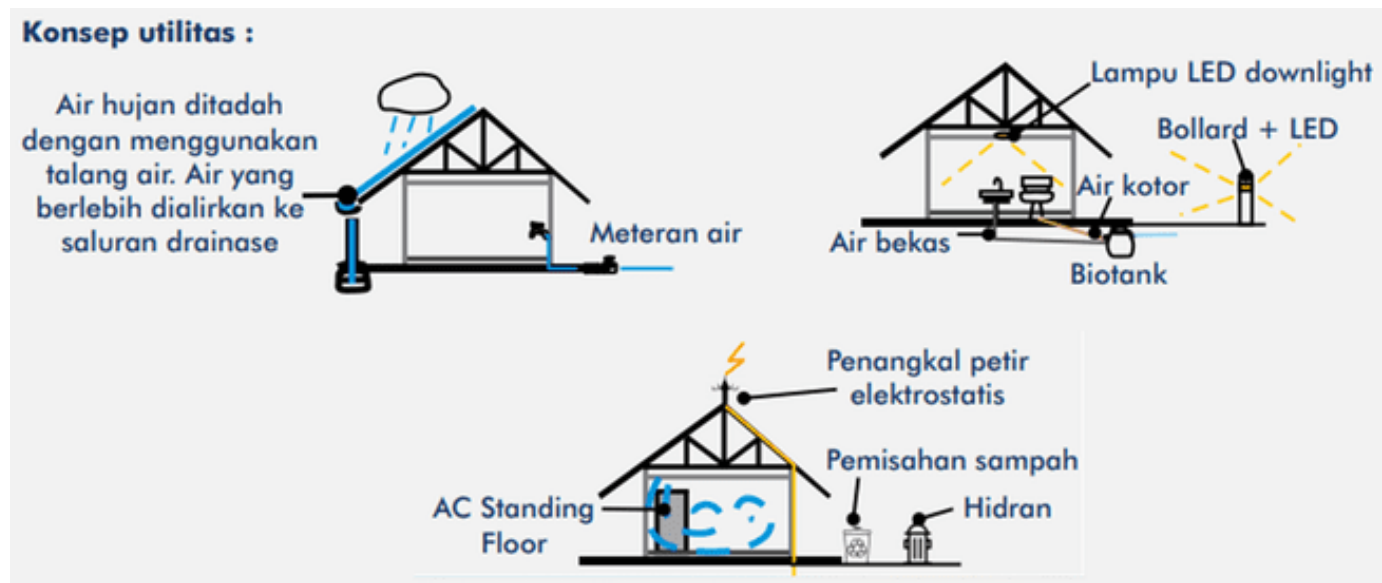

Gambar 5. Konsep Utilitas Pusat Komunitas Sepeda di Kota Pontianak Sumber: Penulis, 2021 
Konsep fisika bangunan Pusat Komunitas Sepeda di Kota Pontianak terdiri atas konsep termal, pencahayaan, dan akustika. Konsep termal membutuhkan strategi termal secara aktif dan pasif. Pesepeda membutuhkan tempat beristirahat untuk mendinginkan tubuh mereka setelah berolahraga di tempat terbuka tanpa AC. Konsep pencahayaan menggunakan konsep memaksimalkan bukaan, sehingga cahaya matahari dapat masuk dan menggunakan energi listrik secara efektif dan efisien. Konsep akustika pada perancangan ini tidak terlalu membutuhkan area yang tenang, sehingga menggunakan tanaman perdu untuk mengurangi kebisingan dari sekitar.

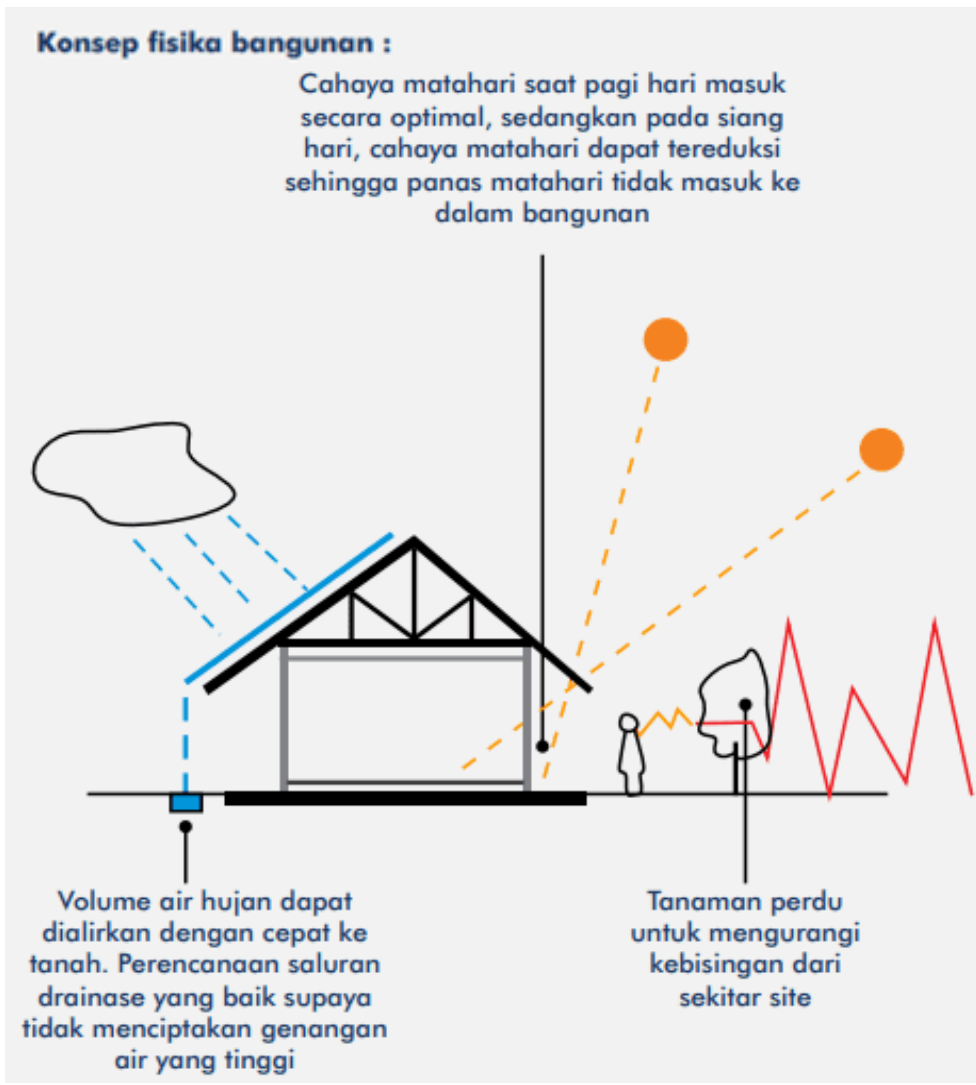

Gambar 6. Konsep Fisika Bangunan Pusat Komunitas Sepeda di Kota Pontianak Sumber: Penulis, 2021

\section{Hasil Perancangan}

Berdasarkan hasil analisis dan konsep, Pusat Komunitas Sepeda di Kota Pontianak terdiri atas 15 bagian, yaitu tempat parkir, plaza dan klaster komunitas sepeda, taman, waterfront, food court, area freestyle, kantor pengelola dan servis, tempat parkir pengelola, taman pengelola, toko sepeda, bengkel dan tempat cuci sepeda, tempat ganti pakaian dan membersihkan diri, toko tempat sewa dan penyimpanan sepeda, tempat pelatihan sepeda, dan toilet umum. Jalur masuk dibedakan menjadi dua area, yakni area depan untuk jalur masuk pengunjung dan area belakang untuk jalur masuk pengelola. Pada area depan, pengunjung yang menggunakan kendaraan bermotor masuk dan belok ke kanan menuju area parkir mobil dan motor, sedangkan pengunjung yang menggunakan sepeda masuk melalui jalur sepeda terproteksi di trotoar eksisting dan melewati bollard untuk memasuki area ini.

Tempat parkir mobil berbentuk linier, sedangkan area parkir motor berbentuk kuldesak atau melingkar yangmenggambarkan ciri khas dari roda sepeda. Area parkir pengunjung terdapat 10 buah parkiran mobil dan 27 buah parkiran motor. Sirkulasi pesepeda dan pedestrian dipisah dengan membuat perbedaan elevasi. Sirkulasi pedestrian ditinggikan membentuk trotoar, sehingga pejalan kaki dapat berjalan dengan aman dan dapat menghindari tabrakan dengan pesepeda. Saat pengunjung 
memasuki area plaza, pesepeda dapat mengelilingi jalur melingkar untuk memarkirkan sepedanya. Setelah parkir sepeda, pesepeda dapat berkumpul di klaster sepeda sesuai kebutuhan komunitas sepeda atau berkumpul di area plaza yang berada di tengah yang dilengkapi dengan podium untuk melakukan acara dan aktualisasi diri, misalnya memamerkan sepeda di podium. Kapasitas maksimal area plaza dapat menampung 400 orang dalam posisi berdiri tanpa menggunakan sepeda.

Area klaster komunitas dilengkapi tempat duduk dan pergola dengan atap menggunakan bahan solar tuff, sehingga pesepeda dapat duduk di area ini tanpa takut terpapar sinar matahari maupun hujan. Atap juga diberi elemen estetis berupa anyaman kayu byoliving untuk area outdoor, sehingga membentuk irama berputar, seperti roda sepeda dan menciptakan konsep bayangan yang indah. Penggunaan material perkerasan pada area klaster komunitas menggunakan kombinasi lantai koral sikat dan rumput sintetis. Pembentukan pola lantai mengikuti jalur yang dapat dilalui sepeda, sehingga area yang tidak dilalui pesepeda dapat diberikan perkerasan berupa rumput sintetis.

Area belakang bersifat privat membentuk pola melingkar membentuk seperempat lingkaran mengikuti irama dalam perancangan dan dibatasi dengan menggunakan tanaman pembatas, yakni pohon pucuk merah. Pada area masuk, pengelola dapat parkir kendaaran bermotor di dekat area taman pengelola dan parkir mobil di dekat kantor pengelola.Area parkir pengelola terdapat 5 buah parkiran mobil dan 38 buah parkiran motor. Pada area masuk pengelola juga terdapat area bongkar muat barang yang telah disediakan tempatnya dengan memundurkan massa bangunan, sehingga kegiatan bongkar muat barang dapat berjalan dengan baik, tanpa mengganggu sirkulasi keluar masuk pengelola.
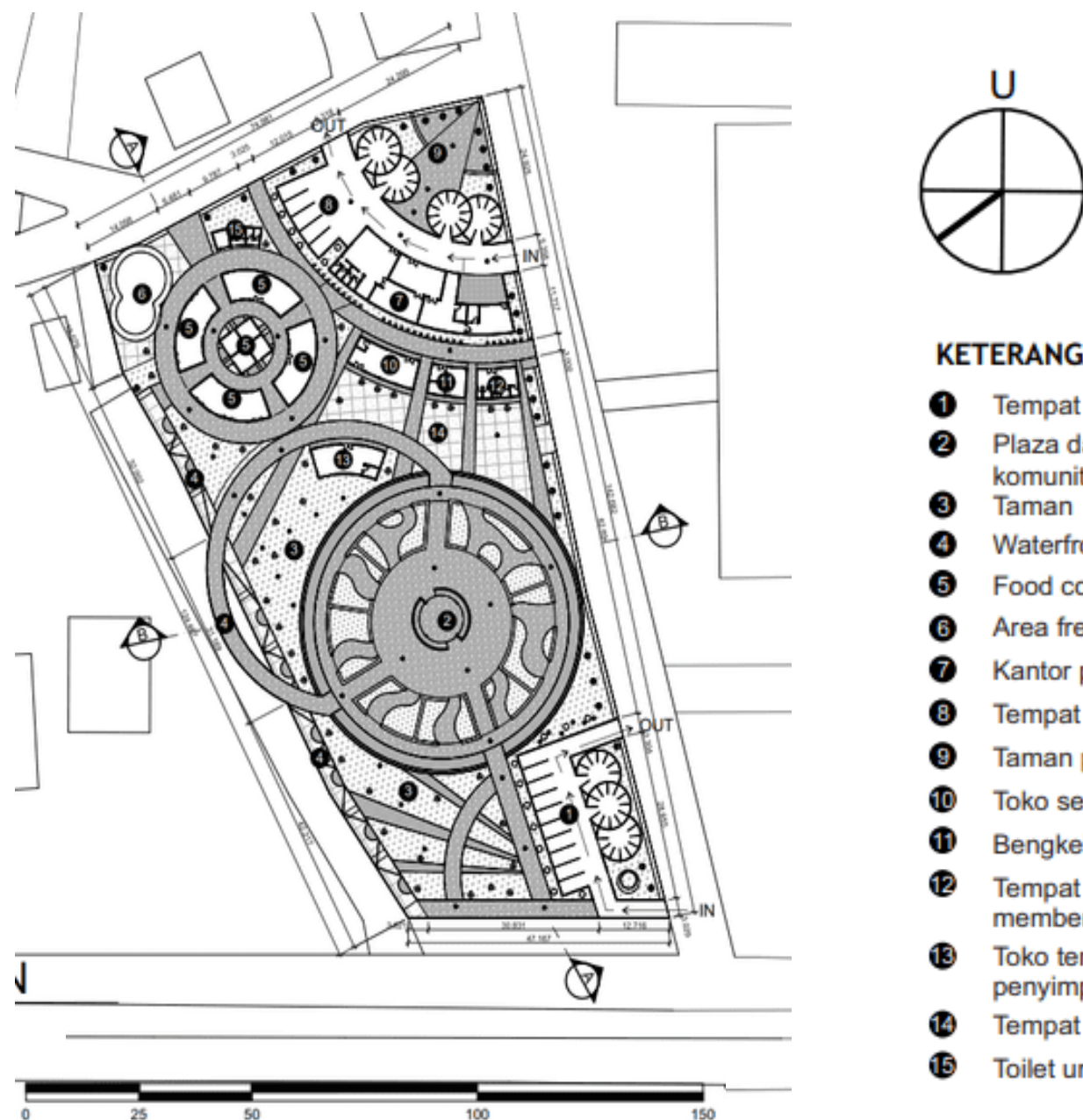
KETERANGAN
(1) Tempat parkir
2 Plaza dan klaster
komunitas sepeda
(3) Taman
(4) Waterfront
(5) Food court
6) Area freestyle
(7) Kantor pengelola dan servis
(8) Tempat parkir pengelola
(9) Taman pengelola
(10) Toko sepeda
(1) Bengkel dan tempat cuci sepeda
(12) Tempat ganti pakaian dan membersihkan diri
(13) Toko tempat sewa dan penyimpanan sepeda
(4) Tempat pelatihan sepeda
(15) Toilet umum

Gambar 7. Site Plan Pusat Komunitas Sepeda di Kota Pontianak Sumber: Penulis, 2021 
Tampak depan kawasan Pusat Komunitas Sepeda di Kota Pontianak merespon orientasi utama ruang terbuka atau plaza sebagai fungsi berkumpul yang merespon Jalan Ahmad Yani dan Jalan Letkol Soegiono. Tampak kiri kawasan merespon view parit. Tampak kanan dan belakang kawasan merespon Jalan Letkol Soegiono. Struktur penarik jembatan menggunakan kabel menciptakan ikon atau wajah baru Kota Pontianak sebagai kota ramah pesepeda yang membentuk roda sepeda. Ikon ini menjadi penanda area ramah sepeda dengan fungsi utama berkumpul, berbagi minat terhadap sepeda, sarana edukasi, dan sarana rekreasi di Kota Pontianak.

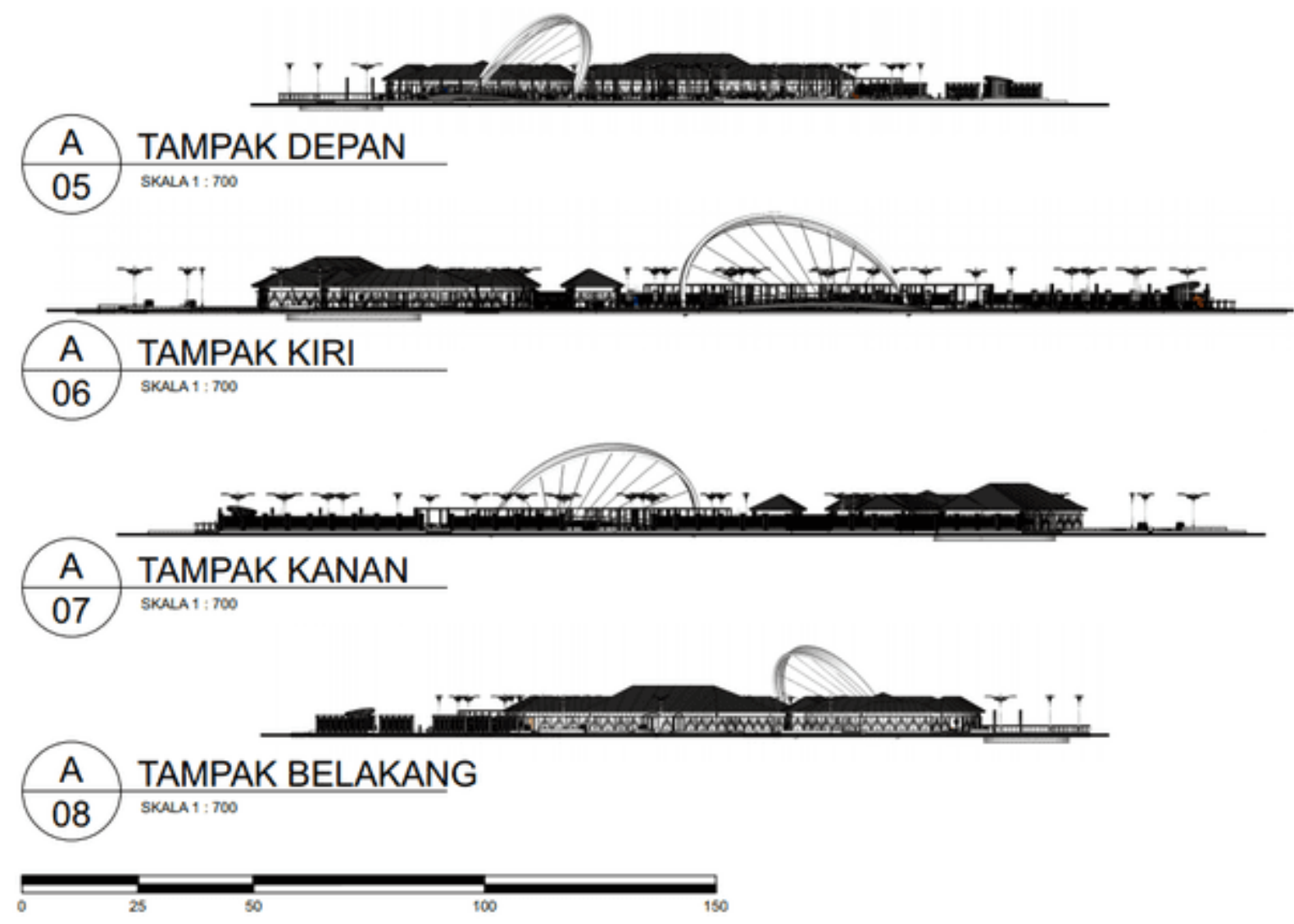

Gambar 8. Tampak Kawasan Pusat Komunitas Sepeda di Kota Pontianak Sumber: Penulis, 2021

Potongan kawasan A-A memotong fungsi komersil dan fungsi berkumpul, yaitu food court, plaza, dan klaster komunitas sepeda. Tinggi dinding bangunan adalah 3 meter. Penggunaan warna netral dan secondary skin dengan karakteristik Melayu Pontianak diaplikasikan ke semua massa bangunan, sehingga karakteristik perancangan menampilkan satu kesatuan dalam perancangan. Secondary skin pada bangunan pada bangunan menggunakan struktur tambahan berupa rangka dari baja komposit dengan bahan penutup panel aluminium yang membentuk corak insang khas Melayu Pontianak. Aplikasi fasad bangunan memperkuat tujuan rancangan untuk menciptakan ikon atau wajah baru bagi Kota Pontianak sebagai kota ramah sepeda yang sejalan dengan tujuan Pemkot Pontianak.

Potongan kawasan B-B memotong area jembatan yang ditarik dengan menggunakan sistem kabel, area plaza, dan klaster komunitas sepeda. Tinggi struktur penarik adalah 11,5 meter dan menarik plat beton jembatan setebal $12 \mathrm{~cm}$. Area jembatan ini membentuk ilusi seperti bentuk tanjak, salah satu aksesoris pakaian untuk laki-laki suku Melayu yang digunakan pada bagian kepala. Area ini bertujuan untuk menciptakan ikon atau wajah baru Kota Pontianak sebagai kota ramah pesepeda. 

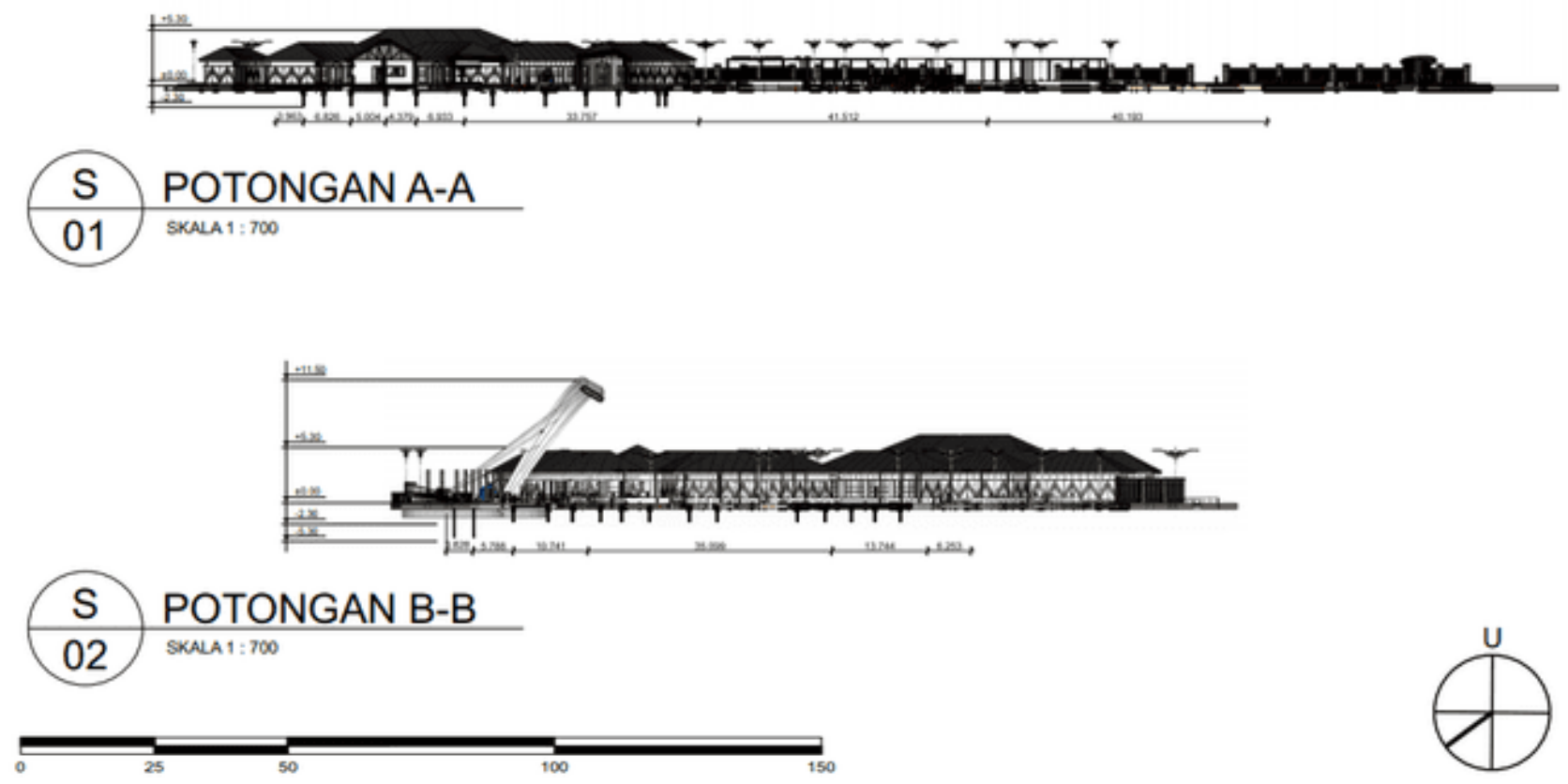

Gambar 9. Potongan Kawasan Pusat Komunitas Sepeda di Kota Pontianak

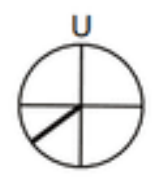

Sumber: Penulis, 2021

Suasana eksterior Pusat Komunitas Sepeda di Kota Pontianak berfokus untuk menciptakan ruang berkumpul sebagai fungsi utama pada perancangan ini. Area pusat untuk berkumpul berperan sebagai wadah bagi anggota komunitas sepeda dan masyarakat umum untuk berkumpul dan berbagi minat terhadap sepeda. Area komersil bertujuan untuk memenuhi kebutuhan pesepeda di Kota Pontianak. Sarana edukasi kepada masyarakat mengenai sepeda terintegrasi dengan area komersil. Area ini dibuat selebar 10 meter dan panjang 38 meter, sehingga pesepeda dapat berlatih keseimbangan sebagai tahap awal belajar sepeda. Sarana edukasi lainnya terdapat area untuk bermain dan berlatih skill sepeda freestyle, yakni untuk sepeda jenis BMX, MTB, dan trial. Area freestyle terletak di belakang tapak supaya pesepeda freestyle dapat bebas berekspresi untuk bermain dan berlatih sepeda tanpa terganggu pesepeda lain yang berlalu lalang. Sarana rekreasi terdapat pada area waterfront dan jalur melingkar yang berperan untuk menciptakan kesatuan dalam perancangan.

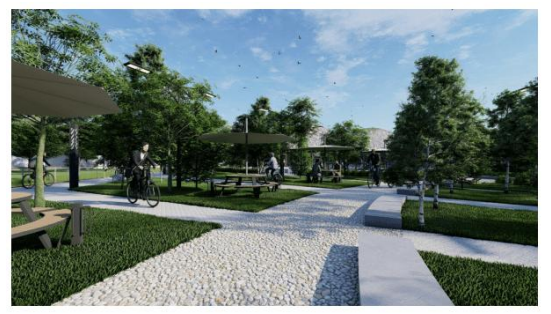

Taman depan

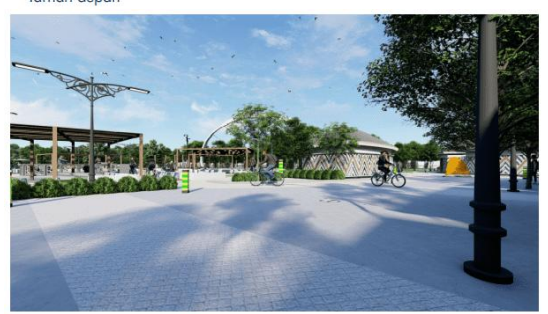

Tempat pelatihan sepedo

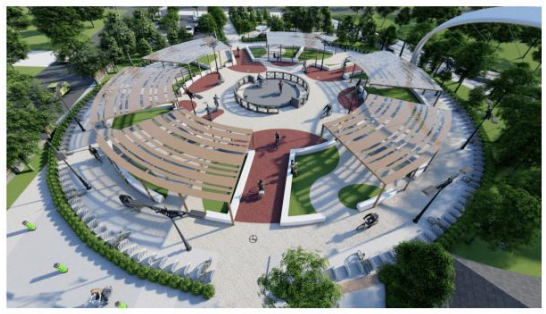

Plaza dan klaster komunitas sepeda

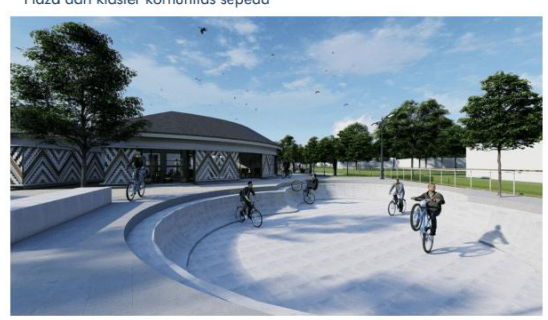

Area freestyle

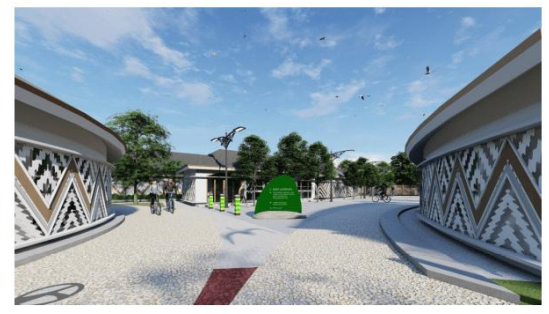

Area komersil

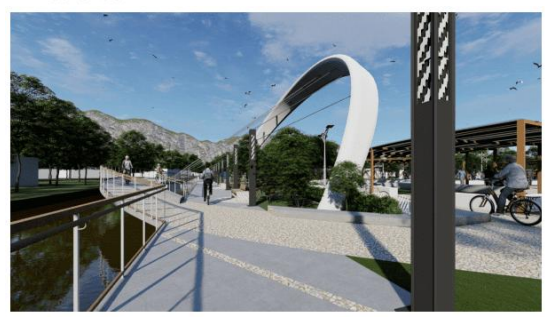

Waterfront

Gambar 10. Suasana Eksterior Pusat Komunitas Sepeda di Kota Pontianak

Sumber: Penulis, 2021 
Suasana interior pada area plaza dilengkapi podium untuk melakukan acara, berkumpul, dan aktualisasi diri, misalnya memamerkan sepedanya di podium. Area podium dilengkapi dengan ramp, sehingga pesepeda dapat menuju area ini tanpa perbedaan elevasi yang signifikan. Suasana food court area outdoor menggunakan pintu lipat kaca, sehingga pengunjung dapat merasakan area luar sebagai bagian dari ruang dalam food court. Jenis penghawaan yang digunakan yakni penghawaan alami dibantu dengan penggunaan kipas uap. Suasana food court area indoor menggunakan pintu dan jendela tertutup, serta penghawaan buatan berupa AC standing floor.

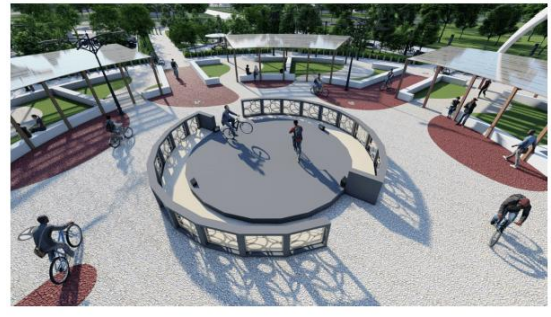

Gambar 11. Suasana Interior Pusat Komunitas Sepeda di Kota Pontianak Sumber: Penulis, 2021

\section{Kesimpulan}

Pusat Komunitas Sepeda di Kota Pontianak menciptakan wadah bagi pesepeda dan masyarakat umum untuk berkumpul (meeting point), berbagi minat terhadap sepeda, sarana edukasi, dan sarana rekreasi, serta terintegrasi dengan area komersil untuk memenuhi kebutuhan pesepeda di Kota Pontianak. Perancangan lansekap dan tata massa bangunan menggunakan analogi roda sepeda sebagai ciri khas perancangan yang fleksibel dan interaktif. Pusat Komunitas Sepeda di Kota Pontianak dapat mengedukasi masyarakat mengenai sepeda, seperti edukasi mengenai parkir sepeda, jalur khusus sepeda, dan fasilitas yang dibutuhkan pesepeda, sehingga dapat mempertahankan tren bersepeda di Kota Pontianak. Jalur sirkulasi melingkar yang ditarik dengan menggunakan struktur kabel menciptakan ikon atau wajah baru bagi Kota Pontianak sebagai kota ramah sepeda sesuai komitmen Pemkot Pontianak.

\section{Ucapan Terima Kasih}

Ucapan syukur kepada Tuhan Yesus Kristus yang telah menjaga dan melindungi saya sehingga dapat menyelesaikan Proyek Tugas Akhir ini, kedua orang tua, para dosen pembimbing Proyek Tugas Akhir yaitu Bapak Dr. Uray Fery Andi, S.T., M.T., selaku pembimbing utama dan Bapak Yudi Purnomo, S.T., M.T., selaku pembimbing pendamping yang telah membimbing, memotivasi, dan memberikan kritik serta saran kepada penulis. Bapak Yeda selaku narasumber yang telah memberikan informasi seputar komunitas sepeda di Kota Pontianak dan referensi desain untuk kenyamanan sesuai kebutuhan pesepeda di Kota Pontianak, seluruh dosen dan staf Program Studi Arsitektur Universitas Tanjungpura yang telah memberikan ilmu yang bermanfaat bagi penulis, serta seluruh teman, sahabat, dan keluarga yang telah memberikan doa dan dukungannya dalam pengerjaan Proyek Tugas Akhir ini, penulis mengucapkan terima kasih.

\section{Daftar Acuan}

Becker, A., Lampe, S., Nugessie, L., Schmal, P. C. 2018. Ride A Bike! Reclaim The City. Berlin: De Gruyter GmbH Chiara, J. D., \& Koppelman, L. E. 1978. Standar Perencanaan Tapak. Jakarta: PT Erlangga

Ching, Francis D.K. 2008. Arsitektur: Bentuk, Ruang, dan Tatanan. Jakarta: Erlangga

Hakim, R. 2012. Komponen Perancangan Arsitektur Lansekap: Prinsip - Unsur dan Aplikasi Desain. Jakarta: Bumi Aksara

Häussermann, M. 2020. E-Bike: A Guide to E-Bike Models, Technology \& Riding Essentials. Colorado: Velopress Snyder \& Catanese. 1989. Pengantar Arsitektur . Jakarta: Erlangga 
JMARS: Jurnal Mosaik Arsitektur, Vol. 9, No. 2, Tahun 2021

Stevenson, J. 2003. The Bike Book. London: Haynes Pub Group

Yeda. (2021, Maret 24). Selasar (Selasa Sepeda Ria). (E. Javiera, Interviewer) 